\title{
The measurement of serum transferrin by iron-binding capacity
}

\author{
W. N. M. RAMSAY \\ From the Veterinary Unit, Department of Biochemistry, University of Edinburgh, Edinburgh, Scotland
}

SYNOPSIS Two criteria which ought to be satisfied by an acceptable method for the estimation of serum transferrin by iron-binding capacity are enunciated. A screening procedure is described which involves the sequential quantitative use of ion exchange and gel filtration. Its use in testing the extent to which two published methods fulfil the recommended criteria is described. Both methods give results for total iron-binding capacity which are $1-10 \%$ high because of the inclusion of non-transferrin iron.

Serum iron-binding capacity is usually measured by adding an excess of iron and measuring the iron retained after the action of a suitable reagent, such as light magnesium carbonate (Ramsay, 1957; Brozovich, 1968), an ion exchange resin (Peters, Giovanniello, Apt, and Ross, 1956; Charlton, Hardie, and Bothwell, 1965), charcoal coated with haemoglobin (Herbert, Gottlieb, Lau, Fisher, Gevirtz, and Wasserman, 1966), or Sephadex G-25 after treatment of the iron-enriched serum with 1,10-phenanthroline and $\mathrm{Na}_{2} \mathrm{~S}_{2} \mathrm{O}_{4}$ (Nielsen, 1968). Iron forms a wide range of covalent complexes which might escape removal by one or other of these reagents, but broad agreement among the methods and the exceptional stability of the iron transferrin complex in slightly alkaline solution give some support for the belief that iron-binding capacity gives an estimate of serum transferrin. If the final analysis is chemical, the result includes the original serum iron and gives the total iron-binding capacity (TIBC). If the added iron is radioactive, the retained radioactivity gives unsaturated ironbinding capacity (UIBC). Total iron-binding capacity should thus correspond to the total serum transferrin and UIBC to that proportion of which the binding sites are not already occupied by the serum iron. If the experimental conditions permit exchange between the original serum iron and the radioactive iron, a falsely high UIBC figure will result. That this does not commonly happen is confirmed by the fact that the theoretical equation TIBC $=$ serum Fe + UIBC is usually experimentally satisfied within narrow limits.

Received for publication 5 July 1973.
Bothwell, Conrad, Cook, Fielding, Hallberg, Izak, Layrisse, and Ramsay (1972) have, however, pointed out that all current iron-binding capacity methods are empirical. Several of the original workers showed that transferrin behaved in the expected way and some tested the effects of possible interfering substances such as citrate or oxalate, but the possibility was never excluded that some of the iron finally measured might not be specifically bound to transferrin. Ramsay (1957) cautioned that magnesium carbonate preparations should be tested before use. Leggate and Crooks (1972) have reported differences in the behaviour of fresh and preserved or lyophilized serum. In their search for suitable standard reference materials and methods Bothwell et al (1972) found wide variations in the analysis of preserved specimens. Williams and Conrad (1972), in an examination of the magnesium carbonate method, found that the use of a barbitone buffer affected the determination of IBC in fresh serum. The electrophoretic investigation of magnesium carbonate supernatants (van der Heul, van Eijk, Wiltink, and Leijnse, 1972) suggested that up to $20 \%$ of UIBC might represent iron bound to proteins other than transferrin, largely albumin and gamma globulin.

There is thus a clear need for critical evaluation of the specificity of iron-binding capacity methods. In theory, a reliable method ought to satisfy two criteria: (1) all the iron retained after removal of the excess should be demonstrably bound to transferrin, and (2) the iron so bound should be the maximum which can be held by the transferrin present. This paper describes a generally applicable procedure which gives definite if not fully conclusive 691 
evidence on the first point and can be adapted to give some information on the second.

Preliminary experiments showed that gel filtration of a magnesium carbonate supernatant gave a single smooth peak of ${ }^{59} \mathrm{Fe}$ with a maximum corresponding apparently to a molecular weight slightly higher than that of albumin, of which the elution peak was judged by absorbance at $280 \mathrm{~nm}$. Recovery of the ${ }^{59} \mathrm{Fe}$, however, was not complete: $2-8 \%$ of the radioactivity in the magnesium carbonate supernatant adhered firmly to the column and could only be easily eluted with citric acid. This was believed to represent iron bound loosely, perhaps to other proteins, and detached in the course of passage through the Sephadex column. That it was not an artefact of gel filtration was proved by rechromatography of the peak containing most of the ${ }^{59} \mathrm{Fe}$, when complete recovery in the same molecular weight range was found. These observations were consistent with the accepted view that most of the iron in a magnesium carbonate supernatant is transferrin. They did not exclude the possibility that some proportion of the iron might be bound to a protein of somewhat similar molecular weight, such as albumin. Gel filtration was therefore preceded by an ion exchange fractionation which separates transferrin completely from albumin. Transferrin passes readily through a column of DEAE-Sephadex at pH 8.0-8.5 at an ionic strength of 0.15 but albumin is strongly retarded unless the ionic strength is substantially increased. These procedures have been combined in a two-stage analysis which is illustrated in figure 1 . It gives quantitative identification of the iron in a magnesium carbonate supernatant (or other iron-binding

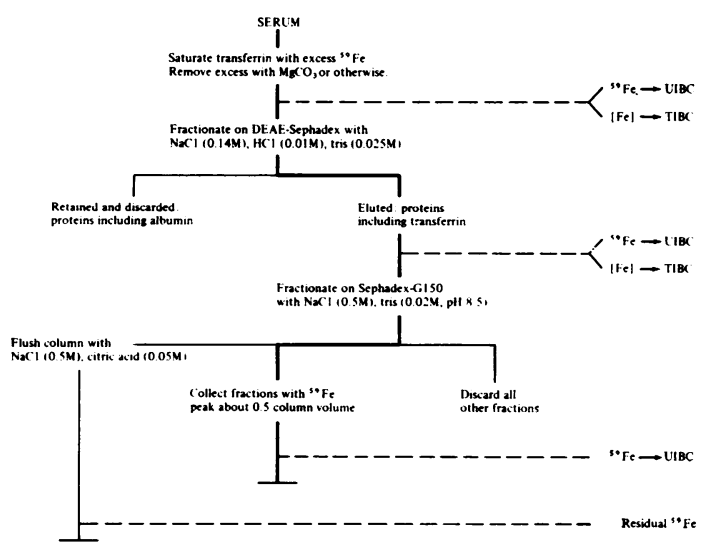

Fig. 1. The evaluation of iron-binding capacity methods (scheme 1). capacity assay solution) which is bound to substance of a molecular weight in the same range as that of transferrin but with the exclusion of albumin. Its. use is illustrated in this paper by application to the magnesium carbonate method and a slightly modified version of the method of Nielsen (1968)온

\section{Methods}

\section{APPARATUS AND REAGENTS}

Small scale separations were conducted in plastie syringes. The best drainage is given by those with an inverted conical base (eg, Becton-Dickinsono Wembley, Middlesex). The bed is supported by glass paper disc (Whatman GF/A) cut from a largein filter circle. Discs are washed with $\mathrm{HCl}(1 \mathrm{M})$ before use. The rate of flow is controlled by a grutio screw in a nylon cuff on a short length of plastic tubing fitted to a fine needle (no. 21). Gel filtratiorf on Sephadex G-150, which requires larger columns, was carried out in acrylic resin columns $30 \mathrm{~cm} \times s$ $4 \mathrm{~cm}^{2}$ (Wright Scientific, Kenley, Surrey).

Sephadex G-25 (fine), Sephadex G-150, and DEAE-Sephadex A-50 (Pharmacia, GB, Ltd) were्ष్ prepared for use according to the manufacturer's instructions and suspended in the buffered sgle solutions described below.

Commercial human transferrin (Behringwer was chromatographed before use on Sephadex G-150. Only the peak fractions comprising about half the material were used. Radioactive ironk solutions were prepared from ${ }^{59} \mathrm{FeCl}_{3}$ in $\mathrm{HC}_{\mathfrak{L}}$ (Radiochemical Centre, Amersham, Bucks). Other reagents were of analytical reagent quality.

\section{IRON-BINDING CAPACITY METHODS}

The $\mathrm{MgCO}_{3}$ method was used in the way described by Bothwell et al (1972), except that the recommendedo amount of saturating radioiron was added in a을 volume equal to that of the serum.

Nielsen (1968) separated the serum proteins, including transferrin, from excess iron after allowing the latter to complex with 1,10-phenanthroline in the presence of $\mathrm{Na}_{2} \mathrm{~S}_{2} \mathrm{O}_{4}$. He used Sephadex G-25 in a column of special design, but good separations are made in this laboratory on columns of fully $10 \mathrm{mIN}$ bed volume in 10-ml syringes. Sephadex G-25 is suspended in $\mathrm{NaCl}(0.14 \mathrm{M})$ containing $\mathrm{HCl}$ $(0.01 \mathrm{M})$ and tris (hydroxymethyl) amino methane $\omega$ $(0.025 \mathrm{M})$. After the addition of the reagents to serum as described by Nielsen (1968), the mixture $(1 \mathrm{ml})$ is pipetted slowly onto the surface of the column. The flow rate is adjusted to $4-5 \mathrm{ml} / \mathrm{hr} .^{+}$ When the serum just disappears completely into $-\frac{0}{6}$ the Sephadex bed, salt-tris solution is pipetted $\stackrel{\circ}{\mathbb{P}}$ carefully on to the surface as required. The initial 
eluate $(3 \mathrm{ml})$ is discarded and the next portion is collected in a tube accurately marked at $4 \mathrm{ml}$, which should contain all the serum proteins and hence all the transferrin-bound iron. It can be used for radioactive assay and chemical estimation of iron or for the subsequent fractionation on DEAE-Sephadex. After each run residual iron is flushed from the column with $4-5 \mathrm{ml} \mathrm{NaCl}(0.15 \mathrm{M})$ containing citric acid $(0.05 \mathrm{M})$ followed by $20 \mathrm{ml}$ salt-tris.

DEAE-SEPHADEX A-50

Columns of 1.5 to $1.7 \mathrm{ml}$ settled bed volume were prepared in $2 \mathrm{ml}$ syringes using DEAE-Sephadex A-50 equilibrated with and suspended in $\mathrm{NaCl}$ $(0.14 \mathrm{M})$ containing $\mathrm{HCl}(0.01 \mathrm{M})$ and tris $(0.025$ M). The solution to be fractionated should be at pH 8-9 and the ionic strength should be 0.13-0.15. The Nielsen eluate described is suitable for immediate use, but the $\mathrm{MgCO}_{3}$ supernatant requires the addition of a small calculated volume of concentrated $\mathrm{NaCl}\left(\mathrm{eg}, 0.03 \mathrm{ml} 2 \mathrm{~N} \mathrm{NaCl}\right.$ per $\mathrm{ml} \mathrm{MgCO}_{3}$ supernatant).

A prepared column is allowed to drain under gravity and placed over a clean, dry tube marked at $4 \mathrm{ml}$. Up to $1.5 \mathrm{ml}$ of a suitable solution is measured accurately onto the surface. The flow rate is adjusted to $4-5 \mathrm{ml} / \mathrm{hr}$, and the liquid is allowed to pass completely into the bed. Small volumes of salt-tris (up to $1 \mathrm{ml}$ ) are added successively, allowing complete drainage after each addition, until the volume of eluate reaches $4 \mathrm{ml}$. The eluate is assayed for radioactivity and iron or may be used for analysis on Sephadex G-150.

SEPHADEX G-150

Columns prepared in $\mathrm{NaCl}(0.5 \mathrm{M})$ containing tris- $\mathrm{HCl}(0.02 \mathrm{M} ; \mathrm{pH} 8.5)$ and sodium azide $(0.2 \%)$ are run by upward flow with the same solution at $1 \cdot 2-1.5 \mathrm{ml} \mathrm{cm}^{-2} \mathrm{hr}^{-1}$. Samples of 1 to $4 \mathrm{ml}$ are applied by gravity flow through a T-junction and fractions of up to $3 \mathrm{ml}$ collected as required. The larger volumes do not give maximum fractionation on columns of the size used, but experiment showed that for routine purposes no detectable error was introduced. After each run residual iron is removed by flushing the column with $10-12 \mathrm{ml}$ salt-citric acid.

\section{ELECTROPHORESIS}

Electrophoresis is carried out in $7.5 \%$ polyacrylamide gel in the discontinuous tris-glycine buffer system (pH 8.5) of Davis (1964). Gels are stained with naphthalene black and scanned in a Gilford scanner at $600 \mathrm{~nm}$.

\section{RADIOACTIVITY ASSAY}

Radioactivity is assayed in a Gamma guard counter (Tracerlab, GB, Ltd) set to give maximum efficiency for ${ }^{59} \mathrm{Fe}$. Only in the gel filtration experiments, where some individual fractions gave very low counts, did the standard error of counting exceed $1 \%$.

\section{IRON ESTIMATIONS}

Iron is estimated by a method modified slightly from that recommended by the International Committee for Standardization in Hematology (1971). The solution $(4 \mathrm{ml})$ is treated with mixed acid reagent (trichloroacetic acid, $1.8 \mathrm{M} ; \mathrm{HCl}$, $0.8 \mathrm{M}$; thioglycollic acid, $0.5 \mathrm{M} ; 1 \mathrm{ml}$ ), mixed thoroughly and centrifuged to obtain a clear supernatant. The supernatant $(4 \mathrm{ml})$ is treated with the chromogen (disodium diphenylphenanthroline disulphonate, $0.04 \%$, in sodium acetate, $3 \mathrm{M} ; 1 \mathrm{ml}$ ) and the absorbance of the stable pink complex is

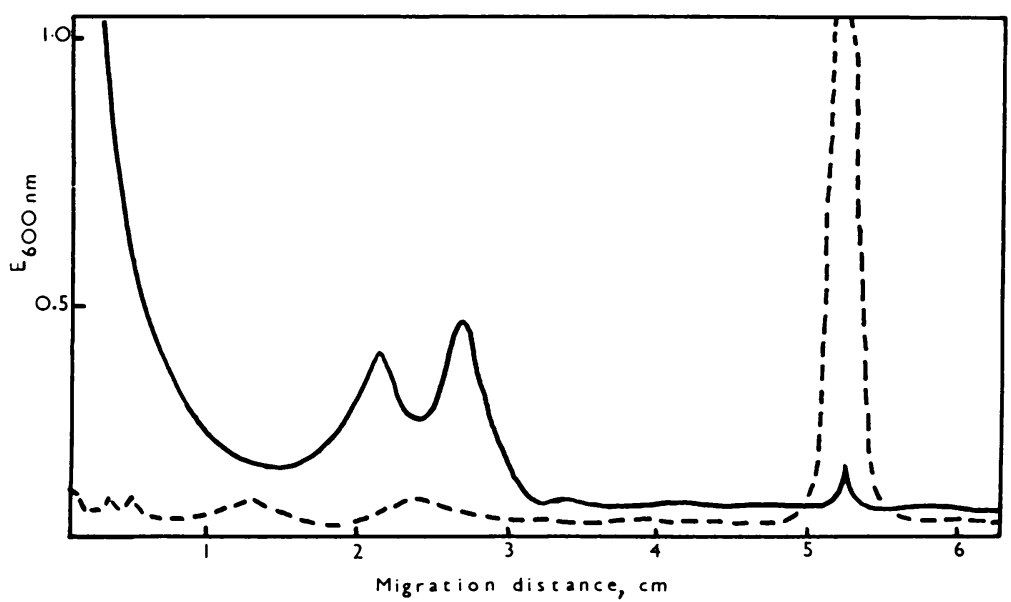

Fig 2 Absorbance of stained electrophoresis gels scanned at $600 \mathrm{~nm}$

------ Serum diluted 1:125

$(0.1 \mathrm{ml}) \longrightarrow D E A E-$ Sephadex eluate from magnesium carbonate supernatant, equivalent to serum diluted $1: 8(0 \cdot 1 \mathrm{ml})$. See text for further details. 
measured at $535 \mathrm{~nm}$. The sensitivity of the method can be doubled by using optical cells of light path $20 \mathrm{~mm}$.

\section{Results}

The validity of scheme 1 (fig 1) as a quantitative test procedure depends both on freedom from adventitious losses of transferrin-bound iron and on the successful separation of transferrin from albumin. The latter point was investigated by making electrophoretic comparisons of DEAE-Sephadex eluate with serial dilutions of the corresponding original serum. The stained gels were scanned. Figure 2 reproduces the recordings obtained from the DEAE-Sephadex eluate from a normal horse serum and the same serum diluted 125 times. Although a detectable amount of albumin survived the fractionation, this was calculated to be less than $0.5 \%$ of the total. In four other experiments (two horse, two human) the DEAE-Sephadex eluate appeared completely free from albumin.

That no transferrin iron is lost on DEAE-Sephadex or Sephadex G-150 under the prescribed conditions is shown by the following results: (1) rechromatography of DEAE-Sephadex eluates on fresh columns of the same reagents (two experiments) gave $99.5 \%$ and $101 \%$ of the applied ${ }^{59} \mathrm{Fe}$; (2) when purified transferrin (1 mg) was chromatographed $\stackrel{0}{=}$ on DEAE-Sephadex, $\mathbf{E}_{280 \mathrm{~nm}}$ measurements gave $\underline{\underline{\sigma}}$

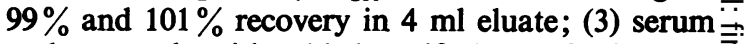
and a sample with added purified transferrin were $\stackrel{5}{9}$ analysed for UIBC and TIBC by the $\mathrm{MgCO}_{3}$ method. 을 Additional aliquots of $\mathrm{MgCO}_{3}$ supernatant were $\frac{\overline{ }}{\mathrm{F}}$ analysed by the scheme 1 procedure. Table I shows $\frac{\bar{\rho}}{\frac{}{\sigma}}$. that although the UIBC and TIBC figures for both $\stackrel{\varnothing}{\Omega}$ specimens were lower after the treatment with DEAE-Sephadex, the component attributable to $\rightarrow$ the added transferrin remained unaltered within reasonable limits of experimental error. The UIBC $\vec{\omega}$ figures in the last two columns of table I confirm $\stackrel{\circ}{\circ}$ that no transferrin was removed by Sephadex G-150.

The results of analyses on Sephadex G-150 of 6 $\mathrm{MgCO}_{3}$ supernatant from (a) fresh serum treated of with excess ${ }^{59} \mathrm{Fe}$, and $(b)$ the corresponding eluate from DEAE-Sephadex are shown in figure 3. The $\frac{\circ}{3}$ major ${ }^{59} \mathrm{Fe}$ fraction gives a peak at $61 \mathrm{ml}$ in fig 3a and $\vec{C}$ 62.5 in fig $3 \mathrm{~b}$, which corresponds in the columns $\mathcal{D}_{\mathbb{D}}$ used to a molecular weight slightly higher than that of albumin. The small fraction of ${ }^{50} \mathrm{Fe}(\mathrm{a}, 2 \cdot 8 \%$, 3 b, $0.3 \%$ ) eluted only with citric acid, is always very low when a DEAE-Sephadex eluate is run on Sephadex and in about $50 \%$ of analyses is zero.

Table II summarizes the results of applying te. procedure of scheme 1 to 12 normal sera fro

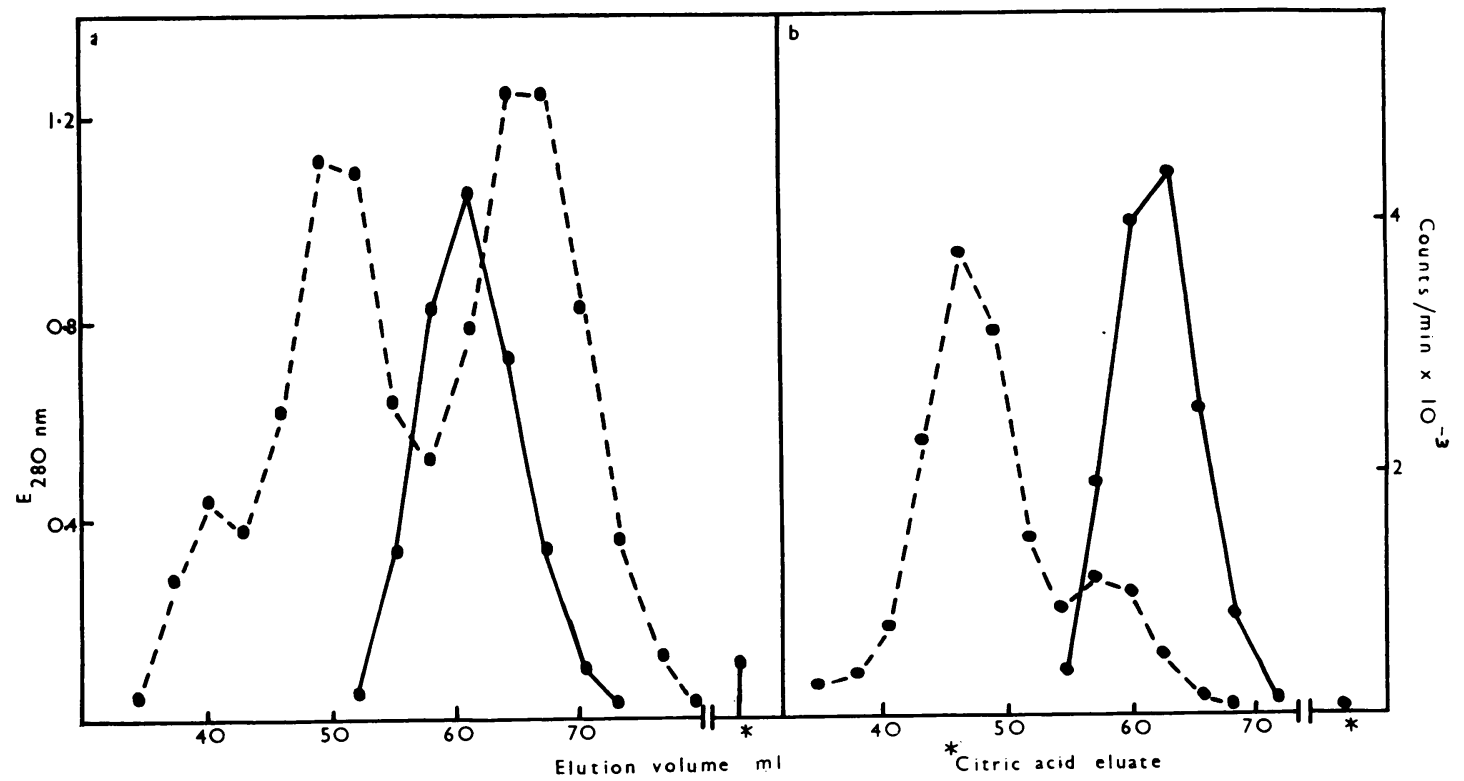

Fig 3 Gel filtration on Sephadex-G150 of (a) magnesium carbonate supernatant; (b) the same after treatment with DEAE-Sephadex. See text for full details.

----- $E_{280 \mathrm{~nm} ;}{ }^{59} \mathrm{Fe}$ counts 


\begin{tabular}{|c|c|c|c|c|c|c|}
\hline \multirow[t]{2}{*}{ Specimen } & \multirow[t]{2}{*}{ Serum Fe } & \multicolumn{2}{|l|}{$T I B C$} & \multicolumn{3}{|l|}{$U I B C$} \\
\hline & & $\mathrm{MgCO}_{3}$ & $D E A E$ & $\mathrm{MgCO}_{3}$ & $D E A E$ & G150 \\
\hline $\begin{array}{l}\text { Serum + Transferrin } \\
\text { Serum } \\
\text { Transferrin (by difference) }\end{array}$ & $\begin{array}{r}150 \\
144 \\
6\end{array}$ & $\begin{array}{l}454 \\
332 \\
122\end{array}$ & $\begin{array}{l}433 \\
306 \\
127\end{array}$ & $\begin{array}{l}299 \\
182 \\
117\end{array}$ & $\begin{array}{l}275 \\
161 \\
114\end{array}$ & $\begin{array}{l}275 \\
159 \\
116\end{array}$ \\
\hline
\end{tabular}

Table I Total and unsaturated iron-binding capacities $(\mu \mathrm{g} / 100 \mathrm{ml})$ of serum with and without added transferrin by magnesium carbonate with screening of results by scheme 1

DEAE = values found after treatment of $\mathrm{MgCO}_{3}$ supernatant with DEAE-Sphadex.

G150 = values found after treatment of DEAE-Sephadex eluate with Sephadex G-150.

\begin{tabular}{|c|c|c|c|c|c|c|c|c|c|c|c|}
\hline \multirow[t]{2}{*}{ Species } & \multirow[t]{2}{*}{ Serum Fe } & \multicolumn{4}{|c|}{ Total Iron-binding Capacity } & \multicolumn{6}{|c|}{ Unsaturated Iron-binding Capacity } \\
\hline & & $\mathrm{MgCO}_{2}$ & $D E A E$ & $1,10-P N$ & $D E A E$ & $\mathrm{MgCO}$ & $D E A E$ & $G-150$ & $1,10-P N$ & $D E A E$ & $G-150$ \\
\hline Horse & 166 & 369 & 366 & 383 & 369 & 204 & 192 & 192 & 200 & 198 & 198 \\
\hline Horse & 144 & 332 & 306 & - & - & 182 & 161 & 159 & - & - & - \\
\hline Horse & 219 & 416 & 384 & 419 & 390 & 193 & 166 & 164 & 176 & 168 & 157 \\
\hline Horse & 153 & 369 & 360 & - & - & 217 & 209 & 207 & - & - & - \\
\hline Horse & 138 & 319 & 295 & 314 & 292 & 184 & 177 & 176 & 172 & 165 & 164 \\
\hline Horse & 253 & 315 & 309 & - & - & 64 & 55 & 54 & - & - & - \\
\hline Calf & 116 & 270 & 255 & - & - & 163 & 145 & 144 & - & - & - \\
\hline Human & 52 & 312 & 280 & - & - & 252 & 218 & 212 & - & - & - \\
\hline Human & 113 & 277 & 245 & - & - & 159 & 138 & 138 & - & - & - \\
\hline Human & 112 & 330 & 316 & 320 & 313 & 213 & 204 & 204 & 202 & 203 & 202 \\
\hline Human & 164 & 343 & 315 & - & - & 160 & 150 & 150 & - & - & - \\
\hline Human & 77 & 313 & 295 & - & - & 236 & 225 & 222 & - & - & - \\
\hline
\end{tabular}

Table II Total and unsaturated iron-binding capacities $(\mu \mathrm{g} / 100 \mathrm{ml})$ in normal sera, illustrating use of scheme 1 to screen results of magnesium carbonate and 1,10-phenanthroline methods.

1,10-PN = 1,10-phenanthroline; DEAE = values found after treatment of $\mathrm{MgCO}$, supernatant or phenanthroline eluate with DEAE-Sephadex; G-150 = values found after treatment of DEAE-Sephadex eluates with Sephadex G-150

human and domestic animal subjects. In all cases the magnesium carbonate method was examined and in four the 1,10-phenanthroline method of Nielsen (1968) was also tested. Treatment with DEAE-Sephadex diminished the magnesium car- bonate TIBC by $20 \pm 11 \mu \mathrm{g} \mathrm{Fe} / 100 \mathrm{ml}$, an average of under $7 \%$. The reduction in UIBC was similar, $17 \pm 10.5 \mu \mathrm{g} / 100 \mathrm{ml}$. Sephadex G-150 removed only an insignificant trace of the ${ }^{59} \mathrm{Fe}$ from the DEAE-Sephadex eluate. Table II includes figures

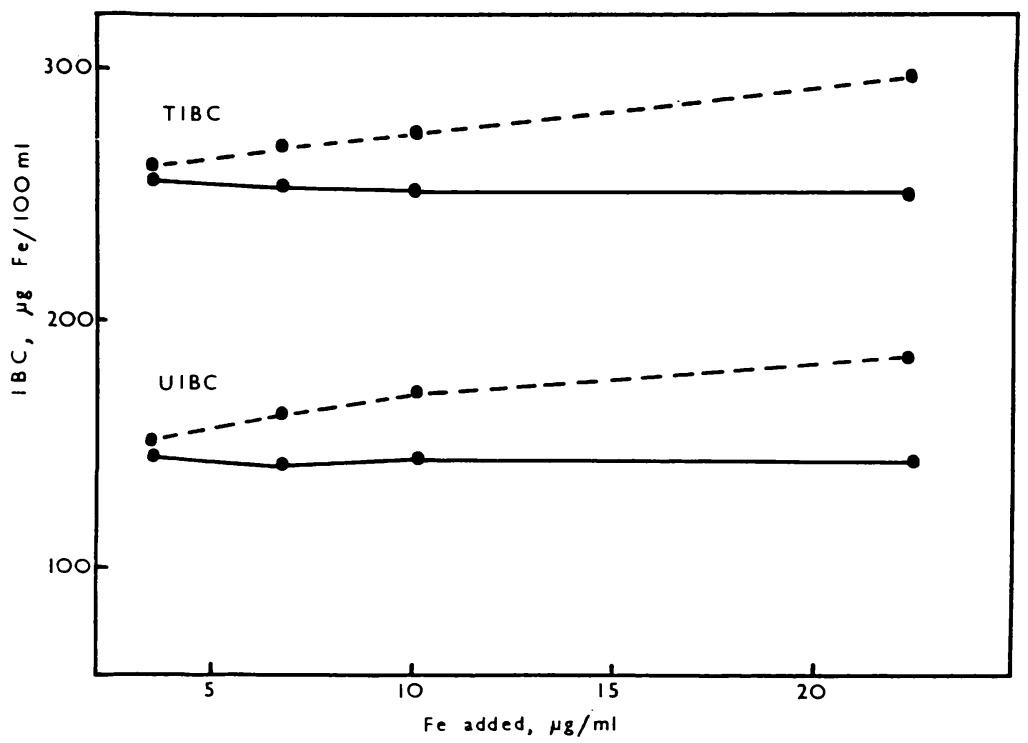

Fig 4 Effect of quantity of iron added in saturating solution on apparent total and unsaturated iron-binding capacities $(\mu \mathrm{g} / 100 \mathrm{ml})$. --_--- magnesium carbonate method. - after treatment of $\mathrm{MgCO}_{3}$ supernatant with DEAE-Sephadex. 
for serum iron, which can be used to show that in every case $\mathrm{SeFe}+\mathrm{UIBC}=$ TIBC. There was thus no exchange of isotope in these analyses. The 1,10phenanthroline analyses gave very similar results.

Ramsay (1957) observed that $\mathrm{MgCO}_{3}$ TIBC tended to increase as the amount of iron used to saturate the serum was increased. Cook (1970), who repeated and extended the observations, thought that the extra iron retained was not transferrin-bound. This is confirmed by the results in figure 4 , which show that it is removed by DEAESephadex.

\section{Discussion}

In the use of scheme 1 it is important to ensure that all transferrin iron is recovered from the ion exchanger, and no generalization, extrapolation, or modification should be made without experimental justification. For example, it has recently been found that sheep transferrin is not completely eluted from the standard size of DEAE-Sephadex column in $4 \mathrm{ml}$ unless the salt concentration of the eluant is raised to a level at which contamination by albumin is difficult to avoid. Again, haemoglobin is not retained on DEAE-Sephadex under the conditions of scheme 1 , so it is still necessary to determine iron by methods with which haemoglobin does not interfere.

The results obtained so far show that both the methods tested give iron-binding capacities which include a small non-transferrin component. The $\mathrm{MgCO}_{3}$ method was found by van der Heul et al (1972), who used different techniques, to have a larger range of error, but this might be explained if they saturated serum specimens with the greater excess of iron originally recommended (Ramsay, 1957).

Since the Sephadex G-150 analysis removes but little iron from the DEAE-Sephadex eluate, either the $\mathrm{MgCO}_{3}$ method or that of Nielsen (1968) could be refined by the introduction of a DEAE-Sephadex step alone. Even this, however, would make them too cumbersome for routine use, and the main use of scheme 1 seems likely to be in the field of evaluation of methods and materials for standard- ization or control of analyses. Although scheme $1 \stackrel{0}{\vec{*}}$ offers no direct evidence on the question whether 을 the iron measured is the max:mum which the trans- $\vec{F}$ ferrin present can bind, such adaptations as that of which fig 3 summarizes the results in the particular case of the $\mathrm{MgCO}_{3}$ method do have a bearing on this problem and add to the usefulness of the procedure.

The author is indebted to R.W. Brown for skilled technical assistance and to his colleagues on the Iron Panel, ICSH, for encouragement and stimulating $\vec{\omega}$ criticism. All the radioactive assays were made on equipment kindly donated by the Agricultural Research Council to the Faculty of Veterinary $\stackrel{N}{O}$ Medicine, University of Edinburgh.

References

Bothwell, T. H., Conrad, M. E., Cook, J. D., Fielding, J., Hallberg, 음 L., Izak, G., Layrisse, M., and Ramsay, W. N. M. (1972). Studies on the standardization of serum and iron binding $\Theta$ capacity assays. In Modern Concepts in Hematology, edited by (D) G. Izak and S. M. Lewis, pp. 69-160. Academic Press, New York and London.

Brozovich, B. (1968). Method for the determination of unsaturated iron binding capacity of serum using radioactive iron and magnesium carbonate. J. clin. Path., 21, 183-188.

Charlton, R. W., Hardie, N., and Bothwell, T. H. (1965). A note on $\vec{\bullet}$ the measurement of the unsaturated iron-binding capacity $8 \mathrm{f}$ serum using radioactive iron. $S$. Afr. J. med. Sci., 30, 71-ఫ․ $\omega$

Cook, J. D. (1970). An evaluation of adsorption methods for measurt ment of plasma iron-binding capacity. J. Lab. clin. Med., 497-506.

Davis, B. J. (1964). Disc electrophoresis. II. method and application to human serum proteins. Ann. N.Y. Acad. Sci., 121, 404-427.

Herbert, V., Gottlieb, C. W., Lau, K. S., Fisher, M., Gevirtz, N. R., 囚 and Wasserman, L. R. (1966). Coated charcoal assay of $\mathbb{D}$ unsaturated iron-binding capacity. J. Lab. clin. Med., 67, 을 855-862.

International Committee for Standardization in Hematology (1971). 응 Proposed recommendations for measurement of serum iron in human blood. Brit. J. Haemat., 20, 451-453.

Leggate, J., and Crooks, A. E. (1972). Problems in quality control in determinations of serum total iron-binding capacity by the magnesium carbonate method. J. clin. Path., 25, 905-906.

Nielsen, I. (1968). A gel filtration method for determining total iron binding capacity in serum. Z. klin. Chem., 6, 103-105.

Peters, T., Giovanniello, T. J., Apt, L., and Ross, J. F. (1956). A new method for the determination of serum iron binding capacity. J. Lab. clin. Med., 48, 274-279.

Ramsay, W. N. M. (1957). The determination of total iron binding capacity of serum. Clin. chim. Acta., 2, 221-226.

Van der Heul, C., van Eijk, H. G., Wiltink, W. F., and Leijnse, B. 음 (1972). The binding of iron to transferrin and to other serum $D$ components at different degrees of saturation with iron. Clin. chim. Acta., 38, 347-353.

Williams, H. L., and Conrad, M. E. (1972). Problems in the measure- $N$ ment of iron binding capacity in serum. Clin. chim. Acta., 37, م 131-140. 